\title{
Philosophical Issues in the Legislation of Islam: Right, Women, and Money
}

\author{
Abdulaziz Omar A. Jughaiman \\ King Saud University, Saudi Arabia
}

Doi:10.19044/esj.2019.v15n14p15 ～URL:http://dx.doi.org/10.19044/esj.2019.v15n14p15

\begin{abstract}
This paper focuses on exploring a contemporary issues in the Islamic legislations as a religion from a scientific and philosophical perspective, approach of Islam with science, and major goals of Islam in terms of rights, money, and woman. It also aims to explore the phenomenon, true concepts, and the concepts of this ideology. Based on these definitions and formulas, a two survey study was designed and used from two stage stratified random sample of cluster. The final sampling units were selected randomly from the primary sampling units (25 families from every count regions) using a systematic random sample. In this present study, it was found that for a chosen country, the Polygamy percentage is about $0.1 \%$ of married female. Only $2.11 \%$ out of the total employed female renders supports to their family. Unmarried females who are 15 years old and over with Pregnancy are less by $24.1 \%$ when compared to unmarried males. There is a high dependence on men in the case of family supporting. In conclusion, successful application of Islam with science depends on the possibility of applying them together. Therefore, the explanations and definitions of many important legislation, phenomenon, and concepts, in addition to some formulas, were suggested. This, however, would have a significant contribution to a better understanding of many phenomena in the religion, ethic, law, economic, society, and politics.
\end{abstract}

Keywords: Philosophy, Religion, Law, Society, Politics, Economy

\section{Introduction}

Engagement of Islam with Sharia name causes an ideological exclusive delayed Islam much more. This is because it gives in its pure language the meaning of raw material. Sharia means law, and Science can accept law more than Sharia. The authentic Secularism is associated with law based on ethics. Otherwise, there is no legislation or rights without ethics while the secularism is depending on the earthly doctrine which is derived from unspecific terrestrial human needs as a creature. Religion depends on god 
or heavenly doctrine and has derived its specific legislations from the god as a creator.

"The philosophy of law deals with various issues that underlie law, especially the existence of a higher value that the secular law can be derived from" (Peter Kunzmann, Franz-Peter Burkard, Franz Wiedmann, Axel Weib, \& George Katorah, 1991).

Moreover, there are many sources of legislation in Islam. The two important sources are; First, The Holy Quran Source which is the creator's words and is subjected to exegetics. Also, the exegetics is subjected to nondiscrepancy beside the time successive of verses and tales.

The Second is SANNA of Prophet Mohamed source which is the creature words and acts. This source is subjected to only certain true tales. Also, the certain true tales is subjected to the exegetics of that tales, which is subjected to non-discrepancy beside the time successive of tales.

However, this paper use simple logical method and presened a brief definition of some concepts. In addition, it uses statistical surveys for the study of certain phenomena and legislation that are unique to Islam within the Islamic community. Hence, the following topics were put into consideration:

- Legislation in Islam

- Racism

- Woman discrimination and equality

- Money between the rich and poor

\section{Legislation in Islam}

The legislation in Islam is built on the absolute ability and absolute knowledge of God. It urges man to comply with the principles of the law and deter man to be responsible to legislate or execute the law with the logic that no one is above the law (God law), no hiding place, no circumvent or contravene of other rights. On the other hand, it reflects the fact that a human being is fallible and that no one is unerring because he is given a selection right. Also, the logic of law is fundamental in religion and, as such, there is no religion without law. This is in addition to time gradation of enactment which entails the fact that to treat an issue or phenomenon in the past still requires dealing with it in the new reality. An example of that is the graduation of prohibition. Thus, it also entails present and prevailing situations as well as future expected situations that may occur. The legal opinions are usually issued by Islamic scholars. To take these legal opinions, we consider the common future of society member and the state that can be subjected to measure it. Also, this is different from individual opinion which is restricted to the individual case because everyone has its special faith. Faith here includes the intent which is invisible. Hence, it cannot be generalized over the society because every society member has his own faith just as a fingerprint 
that cannot be similar. At the same time, it cannot be subjected to measure because this kind of opinion is issued by the individual himself. In addition, individual opinion depends on the knowledge level of everyone.

Permissible in Islam is absolute and it has only one trend, while prohibition is restricted. Prohibition has two trends: the act and the contrition.

Since there is a punishment as a result of the prohibition, any prohibition act restricted to first trend of prohibition does not include who has the contrition. So, the prohibition itself is focused on preventing anyone who is trying to enforce the prohibition. Therefore, Islam requires that if someone has committed any prohibition, it must be kept secret. This is the case if a prohibition by disclosure behavior will lead others to imitate this behavior and later get used to it. Here, the clear rule of legal opinion issued by Islamic scholars is to prevent anyone who is trying to legislate the prohibition.

\section{Case study}

The Jurisprudence rule of the Absolute Prohibition of alcohol in Islam is built on this sentence "If much undergo prohibition, the little would also undergo prohibition" to prevent anyone trying to legislate alcohol. This is with consideration of the quality of alcoholism that started from the first little quantity. Hence, it is called in Arabic language "MODAM" which means continuation.

In reality, little was not prohibited because it is necessary to legalize a prohibition. This resulted to harm based on the degree to legalize the prohibition (emergency case) and the degree to prohibit the permissible (overdose case).

So, from the necessity legislation and from prohibition restricting quality, the "little and much" legislation logic was concluded upon.

This logic is: $\quad$ Little $\leq$ little and much $<$ Overdose.

Permissible $\leq$ little and much $<$ Prohibition.

Since necessity is the mother of invention, the legislation was derived from that need. Therefore, if there is a need to act but that act is prohibited, the need for that act leads to a breaking of the law. Also, there is a need for what can be produced, consumed, or practiced without causing damage to human or his surroundings.

Assuming all acts were forbidden, this means a person can only penetrate all these forbidden. Consequently, there will be nothing forbidden. So, the prohibition of all acts equals the Permissible acts. Therefore, it is not logical that act in its root are forbidden. Forbidden acts refers to those that causes a present or future damage to the person or his environment in a direct proportion. Act takes two qualitative manners; Prohibition manner and Permissible manner. Also, every manner has a quantitative attribute. The quantitative prohibition to be faced with is the quantitative of punishment. 
Therefore, man has sought throughout history to legislate laws and refine acts to diagnose the harmful based on the knowledge of what is favorable and what is unfavorable. Legislation is closely related to knowledge, which makes us conclude on the importance of knowledge contained in the Holy Quran or other resource in the legislation process. The inability of human to control climate change led him to seek the knowledge that enables him to gain more understanding of the climate which in turn led him to legislate based on that knowledge. This is with the aim of reducing the pollution caused by human and which has a significant effect on climate change. Thus, the increase or decrease of freedom depends on all-natural sources, on one hand, and the extent of the fulfillment of human needs on the other hand.

For example, stopping at the traffic red light allows others to pass. Stopping others at that traffic red light allows you to pass as if you share a limited resource with others. Also, when driving vehicle at an average speed and whenever a vehicle enters the road, the space available to the vehicle on the road will be dwindled. In addition, the speed is inversely proportional to time. Whenever someone's vehicle speed increased above the average, there will be a lack of space to accelerate it.

The concept of human acquired rights protection in Islam is wider than many can imagine. For example, the protection of money means the protection of the possibly income of everyone, ranging from his homeland to stone, trees, water, air, and primary resources. It also refers to the space of every foothold which can serve as his source of income. This is because life, money, and development are directly proportional. This helps to avoid any kind of separate development in terms of growth on one side at the expense of another side growth in the society by any reason such as dishonest, unreliable person or group, and unlawful act. From this, it can be deduced that God created the heavens and the earth in truth and when the right is missing, the laws, mathematical equations, and truth are also miscalculated. So, the forbidden in Islam is only a principle. The laws are being derived from the principle. Also, we diagnose the damage of the crime before we determine the damage of the punishment. This helps to determine the appropriate method of punishment depending on the size of the damage, its frequency, type, and the possibility to return right.

\section{Discussion}

There is a principle in Islam that says: "There is life in punishment." Also, there is another principle in Islam that says, "Sedition is tougher than murder." Whereof pose the following queries;

What is the sedition in Islam?

Is capital punishment (death) decidedly for anyone who is convicted with murder? 
The judgment here depends on the causes and motives of the crime, which gives us two results:

- The murderer is not always sentenced to death.

- The non-murderer is not always sentenced to non-death.

The Holy Quran spoke about the story of Prophet Moses: "So, they found one of Our servants, on whom We had bestowed Mercy from Ourselves and whom We had taught knowledge from Our Own Presence."

Here, we will use savior instead of servant. Savior in this story was not to kill a guy unjustly, but because the guy has perpetrated a crime greater than murder. This crime was a tyranny, the guilty was the guy, and the victims were the parents.

Did the savior represent fate or mercy, or does it represent judgment?

Here, we must make it clear that there is no realistic relationship between the savior and the guy, but there is a prior knowledge of the savior about the guy. This is likewise the death of the guy which may occur as death by a natural accident. This happens because of drowning or disease or other natural disasters. Moses who had no prior knowledge about the guy objected, by prima facie, that killing may happen without right. killing, here, is not supporting man to kill man because The Holy Quran also says: "Whoever kills a soul without a soul or corruption in the earth, it is as if he killed all the people and whoever lives a soul, as if he had revived all the people."

When the savior broke the ship, Moses objected, by prima facie, without enough knowledge, that breaking may result to sinking.

Was it a merciful destiny with the owners of the ship, or a judgment in protecting the ship-owners rights?

The savior erected the wall to save the boys treasure. This is done until the boys reach the age where they can protect the treasure all by themselves. Moses objected, by prima facie, without enough knowledge, to the erecting of the wall without hire. Thus, this is in reaction to the refusing of village folk to accommodate them.

(a) Here we consider the neutrality of the savior as a primary motif in the judgment.

Did that represent a destiny or judgment?

1. Therefore, the savior represents a destiny to execute a judgment that achieves justice.

2. In addition, the savior has reflected the realism of human ability.

o Since he did not get rid of the unjust king, so he had to break the ship to make it defective. 
- In addition to an opportunity for change, all human beings are focused on changing an unjust reality or unjust judgment.

o The chance of a possible change in the character of the rapist king, even if that chance was small.

1. Therefore, faith is an alternative force of salvation for the real existence or absence of the Virtuous City, the absence of the rule of law or the spread of political corruption.

2. This savior has been given a miracle like the miracle of the prophets and messengers with the real ability of human, which is the ability to believe in patience and hard work, and not believe in extremism. While the Prophet Mohammed was hiding in the cave, striving for his issue and his life, he was seeking paradise through life and not through death. The terrorist seeks to kill himself, as a way, to run away from life. So, we can say; "if fear is emotional, courage is a moral."

3. Consequently, we can define sedition as any act or word that causes loss of rights.

Therefore, the destiny may be due to wrongdoing by a human: "Your Lord does not oppress anyone" (The Holy Quran). This means that when a human is subjected to injustice, it is not called his destiny, but it is called a wrongdoing by another human. In addition, it is also regarded as an unjust reality caused by human failure or inaction to reform. Islam believes in destiny, justice, and forbade any aggression against either human or nature. Islam believes in God's knowledge of everything that happened and everything that will happen. Here, there is human attempt to know the past and predict the future. In addition, Islam is a belief that each creature future was written in advance. Here, it also causes human to stand out in an attempt to plan his projects in advance in the fields of education, industry, and science. This is considered as a fraction of God's knowledge.

The story of the savior is a historical experience in the legislation, and it is not a story which is an excuse to neglect human rights on the pretext that God will triumph for him. If God wanted to intervene in all human affairs, He would not send messengers or enact laws. God control humans not in the usual sense like humans' control; otherwise, humans could not choose or practice their daily lives with all the desires and instincts. God control humans as He had control over all planets that run in its orbit recording every action on the orbit of time.

One of the other forms of legislation in Islam is the legislation that is related to the human error in worship that has nothing to do with others. It requires forgiveness by several actions, including the liberation of a slave, feeding the poor, and fasting: "liberation of a neck," "Ten poor foods," and "fasting two consecutive months" (The Holy Quran).

However, the logic of this legislation is based on several points: 
- The wrong happened in the worship, not with humans.

- Forgiveness is consecrated on the feeling of other people in the society, including the slaves who are living lives of slavery and the poor people. This forgiveness can be obtained by doing the following:

- Feed the poor

- Slave liberation

- Fasting on behalf of who cannot do "one" or "two" (poor people), which is a type of worship that depends on stopping food and drink throughout the day to achieve a kind of spiritual feeling and serves as a kind of forbearance to get used to.

- God does not need what humans has or can give. So, what humans will serve or give will be returned back to humans. Here, we can link it to The Holy Quran verses: "I have only created Jinns and men, that they may serve Me."

- God does not forgive a person who has wronged another person, whether physical assault, or verbal assault, until the victim takes his right from the aggressor.

Consequently, mistake happened in direct relationship with God, but forgiveness happens for the benefit of human.

\section{Racism}

Who were the slaves?

What means were used to enslave them?

Basically, there were three mechanisms capable of turning a free man into a slave. First of which, was the institution of foreclosure. Second was the deprivation of the rights of a certain person from the protection of his descendants. Thirdly, it was the war for the capture of the prisoners. All these mechanisms are geared towards separating the victim from his original family and excommunicating him from the relative's support. That is, to say, these mechanisms are amputating victim kin relations and transferring him to the family of the owner's relatives" (Eric \& Fadhel, 2004).

Despite the historic condemnations of war crimes, this racialism behavior is still practiced. Consequently, this represents a threat to social and humanitarian because such behavior is trying to amputate a part of society as well as the behavior used in those mechanisms. So, I can liken this to the devil when he disobeyed God. He said that he was created from fire, while Adam was made from clay.

In addition, there is no distinction between white and black, whether on the level of morality or the level of intelligence. The leadership in scientific, moral, social, political, and economic fields are the ones who brought to the world known names from racist societies. They have made a voice and have made political and social gains in their communities. Therefore, racism can be 
defined as a distinction that is based on acquired qualities used in achieving a racist separation, by the will of the authority of the state, in the unfair division of resources and political and human rights. In addition, it is not an issue for a man to associate himself with a woman. The decision is not always political, but it is a choice determined by the circumstances of each. As a result, there is no criterion here for skin color in the issue of racism. Racism in South Africa was not a color racism, but it is rather the meaning of the color. This is because South Africans are no longer suffering from racism although most South Africans are still black. Here, we must be aware of the principle established by this verse: "People, we have created you from a male and a female and made you into nations and tribes that you might know one another. The noblest of you before Allah is the most righteous of you. Allah is the Knower, the Aware" (The Holy Quran). The real meaning of the verse is to know each other's family tribe and nationality. Also, it urges to maintain these affiliations; family, tribe, and (in this age) nationality as identifiers for people.

\section{Discussion}

For many Saudi folks, there is a tribe custom especially for marriage, and this custom is only applied to Saudi nationality. This can be seen in Figure 1.

\begin{tabular}{|l|l|l|l|}
\hline \multicolumn{2}{|c|}{ People Of Saudi Nationality } & \\
\hline Belong To Tribe & OR & Do Not Belong To Tribe \\
& Freed & Early Emigrant \\
$\qquad$\begin{tabular}{|l|l|}
\hline People Of Non-Saudi Nationality \\
Tribe Is Not Applied \\
\hline
\end{tabular} \\
Source: The Author \\
\hline
\end{tabular}

Figure 1. Saudi society and custom of marriage

This custom is a genealogy criterion. For any fiancé or fiancée to be acceptable by fiancée family, or by fiancé family, she or he must belong to a tribe. Does this custom represent a racist? And if yes, why?

However, this custom does not actually represent a racist because:

1. There is no superiority over ethnic group because of equal rights in the society, work, and religion.

2. This is considered since there is no interference from the state based on the issue of affinity or marriage (the non-interference of the state which, here, it is a form of liberalism). Thus, it is a family affair for each family. It represents the difference between a culture belonging to a tribe and a non-tribe in the sense of the harmony of cultures in same society. As in many countries, there is a kind of differentiation through the wealth level, political, or social status away from the tribe. 
The overlap between wombs as an Islamic fundamental with this local custom has made attempts of contravention for this criterion result to amputation of this womb or fundamental. Hence, this does not apply to nonSaudi nationality because:

- Non-Saudi nationality was part of their society. By the way, there are many succeeded marriage cases for Saudi nationality belonging to tribe with non-Saudi nationality.

- Their nationality represents a kind of relationship claims such as the tribe.

- In addition to what was previously said, the ideality is different from country to country.

- Here, the criterion of custom is vanishing because of the vanishing of the topical comparison. Also, this is because of the vanishing of the other member of same society who is subjected to this custom criterion, or common society criterions, by fiancée family or by fiancé family.

- There is no local relation between non-Saudi nationality with any Saudi that does not belong to a tribe, which is likely to make a genealogy overlap.

Nevertheless, it is just a choice. Here, the family has an important role to play in influencing that choice. The criteria for family acceptance include moral, wealth, social, and cultural criteria. Also, the choice is not limited to the decision itself, but to the result of that choice. This means that you choose the decision and the result of that decision.

For example, the decision for a woman to get married may depend on two decisions; the woman and her family. After marriage, the decision will depend on the woman and her husband.

Also, we consider the family name which is a common right to all members as the name of the tribe and nationality. Here, the verse does not stipulate the marriage between peoples or tribes or families and individuals. At the same time, it does not deny this marriage, but it is the affiliation of those identifiers which are used to gain recognition. In common practice, after marriage, the children belongs to the father and the woman belongs to her husband.

Nationality is indispensable for the identification of individuals worldwide. Therefore, "the most honored of you in the sight of God is the most righteous of you." This, however, explains the importance of respecting the laws of God in the estimation process to people, or individual's behavior. This can be perceived through laws related to transactions. The verse also offers a human truth since the time of Adam. Thus, the nation's progress is directly proportional to the level of ethical commitment. Also, any individual can express his respect for this verse or his commitment by respecting nations that were devoted to this verse or their commitment. This also clarifies the civilized rule of human community that is divided into two large categories: civil who the civilization is ascribed to them by their constancy and 
constructive nature, and nomad who are usually looking for livelihood everywhere in any case.

\section{Woman Discrimination and Equality}

When talking about women's rights and their claims for equality, it is clear there is an important aspect in which women are equal to men. This aspect is the humanitarian aspect. Logically, there is no absolute equality between discriminated beings. So, if we divide the components of nature, we will find that all parts are incomplete. Also, we cannot find absolute equality for all components of nature that is not based on its characteristic separately as we will fall between two stools, or we will be in an outright futility. Nevertheless, we can achieve equality in the rights with regards to the characteristic of woman and the characteristic of man.

Absolute equality makes a kind of surface confined to particular culture or community. It aims at creating a kind of permanent quarrel between them. This was considered since they are both fundamental components of human and society. Also, this equality must take into consideration the responsibility as well as the result of this responsibility. This can be seen as the extent of women's ability "to put up with" any kind of penalty.

The fundamentally functional social relation between man and women is a complementarity relation, while this relation between man and man or woman and woman is a competitive one.

Every relation has its own emotions that reflect the truth of that relation. Love is sometimes a kind of care and attention shown by the mother and father to their sons and daughters. It is a love that is non-collapsible or that cannot be displaced. Whilst the relation of friendship or other kinds of love is subject to many variables, the most supreme were the capability to find alternative. As a result, complementarity takes place in any restrained relation, while the competition may take place in any unrestrained relation.

The lack of woman in the mind and religion, in some of an inaccurate interpretation of the Holy Quran or Hadiths, does not mean the absolute lack as women cannot perform fully in the task of worship (whereas women in Islam are prevented from some worship task because of menstruation or maternity). In addition, women cannot participate fully in men society.

This is because someone usually remembers what he likes and ignores what he dislikes. "Call to witness two witnesses of your men, if the two are not men, then a man and two women from the witnesses whom you approve; so that if one of the two errs, one of them will remind the other" (The Holy Quran). "Err" here is not a kind of being forgotten but is regarded as a kind of being incurious or not used to. By the way, this is an important idea in shortestroute problem based on the time objective. This helps in completing a job within the shortest time by allocating every kind of job to everyone separately. 
Consequently, those who are used to doing a specific job will have more experience in it. This can be illustrated in Figure 2.

\section{Experienced}

jop 1 by worker 1 , jop 2 by worker 2 Route 1 (Time)

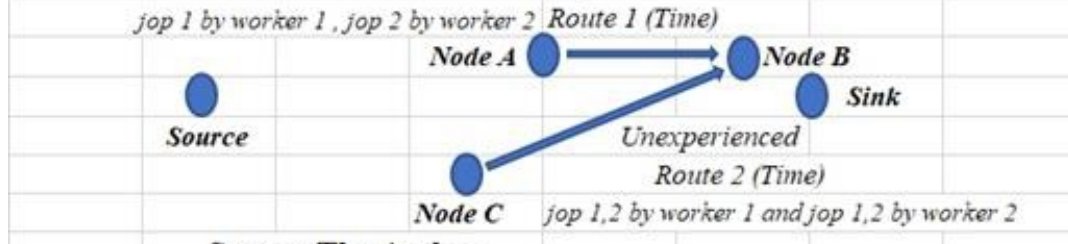

Source:The Author

Figure 2. Shortest-route for time objective, where the experienced will complete their job within the shortest time.

"O Humankind fear your Lord, who created you from one soul and created from it its mate and dispersed from both many men and women. And fear Allah, through whom you ask one another, and the wombs. Indeed, Allah is ever, over you, an Observer." The similitude of Jesus before Allah is as that of Adam; He created him from dust, and then said to him: "Be". And he was" (The Holy Quran). Here, we can deduce the issue of complementarity relation of woman with man and competition relation of woman with other woman or man with other man. Therefore, this is in addition to other potentials relations between man and woman that was suggested (Figure 3).

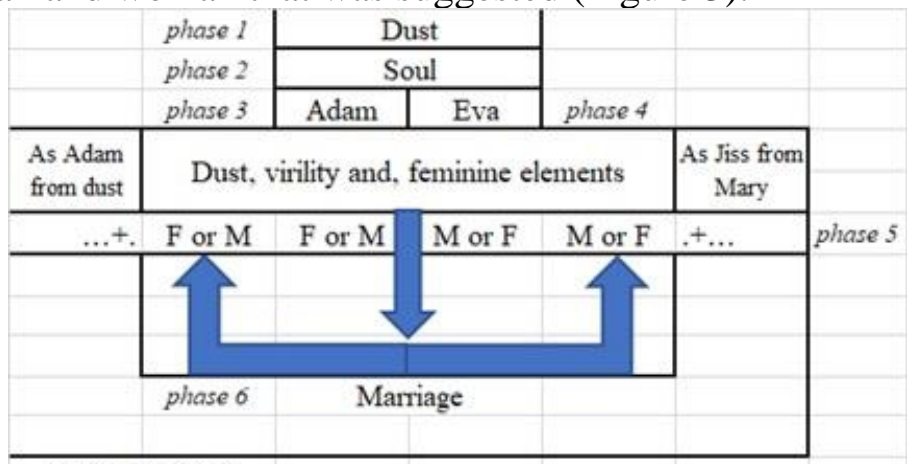

Source: The Author

Figure 3. Dependence on the holiness of womb, "no way for any kind of incest"

Consequently, that must not take the lead in terms of any backward development of reproduction by cloning. Also, we should derive the equality concept based on the role of woman and man in the existence of life. Here, the choice of woman is granted to her from the creator as a fundamental right built on the perfection of human creation.

Women's role in the maternity task includes capability of pregnancy, childbirth, breastfeeding, and custody. Then, the men perfection on the side of other tasks and transactions does not result to a shortage of women. At the 
same time, the common perfection had enabled them to learn, participate, and influence the development of science together. The mental capacity of women in the achievement of education is not less than that of men, with consideration of the relativity variance. So, we can use the game theory which is "concerned with the actions of decision makers who are conscious that their actions affect each other" (Eric Rasmusen, 1989). Thus, the difference arises based on the role of emotion. Emotions such as fear, restlessness, joy, sadness, hope, hopelessness, love, jealousy, and hatred represent the dimensions of the human psychology which reflects the range of human tendencies among the opposite ends. It has a direct and indirect impact based on their response to the logic thinking or their lack of it.

This can also be seen from the decision besides experience, through the antithesis or balance of those feelings. For example, fear may lead to doubt, then doubt leads to hesitance in decision, which then leads to weak decision.

In the research laboratory, the role of emotion decreases its effect. In social life, emotion has a changeable and sensitive nature, and it had significant influences on the decisions. Here, this emotion needs the man's support. In addition, the baby's descent name is taken from the man's name instead of the name of the woman. This, however, proves the cause of the birth (Figure 4).

\begin{tabular}{|c|c|c|c|c|}
\hline \multirow{2}{*}{ unclear responsibility } & & Woman & & \multirow{2}{*}{$\begin{array}{l}\text { The baby name is baby of } \\
\text { woman and unbeknown }\end{array}$} \\
\hline & Man & baby & Man & \\
\hline \multirow{2}{*}{ clear responsibility } & baby & Man & baby & \multirow{2}{*}{$\begin{array}{c}\text { The baby name is baby of } \\
\text { woman and man }\end{array}$} \\
\hline & Woman & & Woman & \\
\hline
\end{tabular}

Source: The Author

Figure 4. Descent of the baby

This is also demonstrated by the statistical fact of procreation; $a$ man and more than women is more procreation probability than a woman and more than man. That can be applied in Markovian birth processes. For a society with a population number $N$ at a specific time $t$, the values that $N(t)$ takes are the population growth processes (states) and the probability is $P \square(t)$, whereas $N(t)$ integer, $N(t) \geq 0$ (Richard, Hassan \& Mohammed, 1988). Here, we have a variable relevant to every special case (for every husband: a wife or more; $1: 1,1: 2,1: 3,1: 4)$.

Among the legislations that are specific to Islam, there is a kind of discrimination based on the issue of Inheritance and polygamy. These issues are interrelated with each other to justify each other. As for inheritance laws, the legislation is considered to be the characteristics of the prevailing reality according to many facts. These facts include: 
1. Man is responsible for family support such as the cost of childbirth, breastfeeding, and custody.

2. The woman's livelihood dependence is on her husband or her parents. This plays an important role in the inheritance law.

3. Polygamy if any.

4. There is restriction of wealth transference in the same family (Figure $5)$.

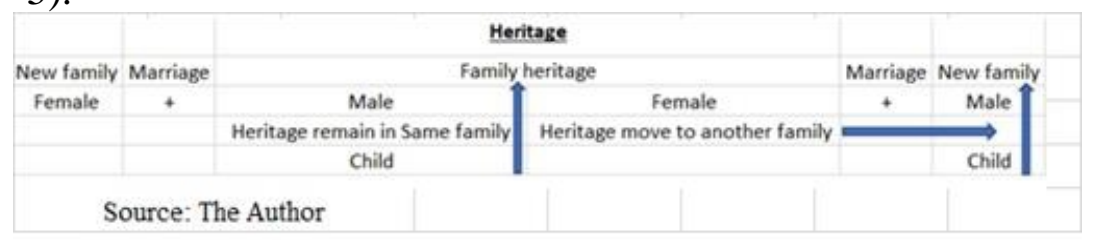

Figure 5. Transference of wealth

Here, legislation considers the importance of circumstantial status, the repetition, and the continuity of current status. In our time, men in many Muslim societies are still responsible for the family running with consideration of the conditions of polygamy. Subsequently, polygamy has the following quality:

1. The justice conditions.

2. An individual decision depends on how long the first woman's relationship will continue if the man wants to multiply. (man and woman decisions)

3. An individual woman decision if she does not have a chance to get married. Or if she is looking for a special standards. (a woman decision)

4. The case of looking for a chance to have children. (man and woman decisions)

5. Solidarity target. (man and woman decisions)

6. Legislation relating to the laws of polygamy is a matter of permissible and not of obligation. It is also a matter that is undesirable if it leads to a case of divorce.

7. If we assume the prohibition of polygamy then, we would replace any potential legal relationship in accordance with contract that protects the right of everyone, especially that of women and potential children.

Furthermore, legislation of the inheritance considered the importance and priority role of women and men in the family .

From the above and through Table 1 below, the following points were drawn: 


\begin{tabular}{|c|c|c|c|c|c|c|c|c|c|c|c|}
\hline \multirow{3}{*}{$\begin{array}{c}\text { Age } \\
\text { Groups }\end{array}$} & \multicolumn{11}{|c|}{ Marital Status \& Gender } \\
\hline & \multicolumn{3}{|c|}{ Total } & \multicolumn{2}{|c|}{ Widowed } & \multicolumn{2}{|c|}{ Divorced } & \multicolumn{2}{|c|}{ Married } & \multicolumn{2}{|c|}{ Never Married } \\
\hline & Total & Females & Males & Females & Males & Females & Males & Females & Males & Females & Males \\
\hline $15-19$ & 1789169 & 878743 & 910426 & 298 & 0 & 896 & 0 & 26153 & 1372 & 851396 & 909054 \\
\hline $20-24$ & 2018057 & 964084 & 1053973 & 790 & 36 & 8908 & 1280 & 250808 & 36877 & 703578 & 1015780 \\
\hline $25-29$ & 1936400 & 957520 & 978880 & 2868 & 0 & 19306 & 8631 & 599723 & 317421 & 335623 & 652828 \\
\hline $30-34$ & 1747732 & 866098 & 881634 & 2619 & 724 & 32322 & 13226 & 668332 & 621829 & 162825 & 245855 \\
\hline $35-39$ & 1527519 & 754229 & 773290 & 9239 & 430 & 26707 & 14356 & 620151 & 662483 & 98132 & 96021 \\
\hline $40-44$ & 1284333 & 629836 & 654497 & 15588 & 1197 & 22756 & 11771 & 548243 & 602133 & 43249 & 39396 \\
\hline $45-49$ & 1070154 & 520252 & 549902 & 26718 & 2081 & 16209 & 7750 & 457574 & 514800 & 19751 & 25271 \\
\hline $50-54$ & 853081 & 414429 & 438652 & 43932 & 1505 & 14573 & 8990 & 344275 & 418997 & 11649 & 9160 \\
\hline $55-59$ & 655841 & 314017 & 341824 & 54110 & 2551 & 10453 & 7212 & 245106 & 326011 & 4348 & 6050 \\
\hline $60-64$ & 479334 & 231687 & 247647 & 57261 & 3428 & 6548 & 6467 & 165598 & 234588 & 2280 & 3164 \\
\hline $65+$ & 854281 & 436889 & 417392 & 215652 & 17466 & 9385 & 5166 & 206700 & 390859 & 5152 & 3901 \\
\hline Total & 14215901 & 6967784 & 7248117 & 429075 & 29418 & 168063 & 84849 & 4132663 & 4127370 & 2237983 & 3006480 \\
\hline
\end{tabular}

Table 1. The General Authority for Statistics Kingdom of Saudi Arabia, Demographic Research Bulletin 2016

Through this simple equation, we can obtain the polygamy figure; where $k$ and $n$ are the group interval. Therefore;

polygamy rate $=\left[\sum_{k=15}^{n=65+}\right.$ married female $-\sum_{k=15}^{n=65+}$ married male $] \div$

- $\sum_{k=15}^{n=65+}$ married female.

unmarried female with pregnancy capability to unmarried male $=$

$\left[\sum_{k=15}^{n=49}(\right.$ widowed females + divorced females + never married $\left.)\right] \div$

$\sum_{k=15}^{n=65+}$ (widowed male + divorced male + never married male +

- $($ polygamy rate $) \times$ married male $))$

Subsequently, these figures are:

- The percentage of polygamy female is $0.1 \%$ of the total married female.

- Unmarried female within the age group of 15 to 49 years (with capability of pregnancy) represents a $76.9 \%$ of the total number of unmarried men. So, this percentage of women who can marry and are capable of becoming pregnant is less by $23.1 \%$ compared to unmarried men. Hence, this indicates the scarcity of women in the society. This significant difference explains the importance of women in family formation, and the society tendency towards this role. Also, it aims to give priority over other roles and explains the society opinion towards women. Therefore, woman role is determined by the logic of appropriate role, not by the logic of man's superiority. Also, this significant difference explains the limitation of the capability to multiply which is another reason to increase this significant difference. This case is seen especially when the marriage decision is optional.

In the subject of family support from Table 2, we can obtain the figure of family support by woman through this simple equation;

* (Total of widowed employed female $) \div$ (Total of employed female). 


\begin{tabular}{|c|c|c|c|c|c|c|c|c|c|}
\hline \multicolumn{10}{|c|}{ Saudis Labor Force (15 Years and above) by Marital Status and Sex } \\
\hline \multirow{2}{*}{$\begin{array}{c}\text { Marital } \\
\text { Status }\end{array}$} & \multicolumn{3}{|c|}{ Employed Persons } & \multicolumn{3}{|c|}{ Unemployed Persons } & \multicolumn{3}{|c|}{ Total } \\
\hline & Male & Female & Total & Male & Female & Total & Male & Female & Total \\
\hline $\begin{array}{l}\text { Never } \\
\text { Married }\end{array}$ & 924,058 & 187,128 & $1,111,186$ & 225,207 & 216,279 & 441,486 & $1,149,265$ & 403,407 & $1,552,672$ \\
\hline Married & $3,204,288$ & 577,099 & $3,781,387$ & 27,534 & 207,514 & 235,048 & $3,231,822$ & 784,613 & $4,016,435$ \\
\hline Divorced & 47,114 & 53,851 & 100,965 & 1,367 & 14,856 & 16,223 & 48,481 & 68,707 & 117,188 \\
\hline Widowed & 10,393 & 17,648 & 28,041 & 0 & 1,027 & 1,027 & 10,393 & 18,675 & 29,068 \\
\hline Total & $4,185,853$ & 835,726 & $5,021,579$ & 254,108 & 439,676 & 693,784 & $4,439,961$ & $1,275,402$ & $5,715,363$ \\
\hline
\end{tabular}

Table 2. The General Authority for Statistics Kingdom of Saudi Arabia, Labour Force Survey, Q3 2016

- Approximately $2.11 \%$ of Saudi Labor female Force supports their family. Also, they are subjected to these conditions:

○ Widowed female cannot have her dead husband's pension.

- The man supports the children of his divorced woman.

- Never married females are supported by their parents.

Here, there is a high dependence on men in the case of family supporting.

\section{Discussion}

Is it possible to make a comparison between two women of two different societies?

To answer this question, we assume the following:

A Saudi woman in Saudi Arabia wears a uniform that matches a woman's dress in western country. Also, western women in western country wear a western women's dress. They practice their daily lives in the street and work. Also, we assume that they are ethically equal. So, western woman dress and customs are an acceptable part of the society in which she lives. Therefore, she has gained self-immunity against any bad behavior or bad repute. On the other hand, a Saudi woman in a western woman uniforms and customs are rejected by the society in which she lives. As a result, she is considered not to be a part of the society. In addition, her immunity would be weak for any bad behavior or repute. Subsequently, this invites us to talk about Islamic dressing in an Islamic country or in non-Islamic country.

The face veil is acceptable in the Islamic community and this corresponds to the Holy Quran; "Tell thy wives and daughters, and the believing women, that they should cast their outer garments over their persons (when abroad): that is most convenient, that they should be known (as such) and not molested. And Allah is Oft-Forgiving, Most Merciful" (The Holy Quran). 
In western society, if they should be known only through the veil, then they may be a disrepute or slanders which may lead to a kind of seclusion. Therefore, it may not always be compatible reasonably, especially with the verse.

- In every society, there are prevailing customs and recessive customs. Prevailing customs are acceptable, while recessive customs are often rejected.

- Being disreputable or slanderous is a result based on the reaction of the recessive customs.

- However, prevailing customs are taking any acceptable custom while recessive customs are usually rejecting most of the customs especially the strange ones.

- So, we can conclude that ideality is not absolute. That is to say, the ideal model in a society differs from the ideal model in another society.

\section{Money between the Rich and Poor}

Islam from the onset is a call to feed the poor with a promise in paradise. Its legislations differ from socialism by these points:

- Legalize the ownership which is a principle of capitalism.

Also, Islam approach socialism from this point of view.

- Forbid Poor profiteer.

The words money, rich, and poor in Islam often evoked from the word "zakat". Zakat differs from tax as a fixed ratio that is directly proportional to the non-consumed or stored material value. Also, it is cumulative annually as long as the value has not been developed or invested in. The logical understanding of zakat is not just as a collection for charity, but is based on the wisdom of the rotation of money between the rich and the poor. The important outcome of its wisdom exists in terms of investment. It motives the circulation, investment of money, and the employment of resources. Here, we presented an explanation of the main distinctive quality between money and other kinds of treasure, such as gold and silver, which have an increased value with time. This is in addition to some commodity like as wine or other kind of food depending on the period of saving. Therefore, it is to be garnered. On the other hand, money has a decrease value with time and cannot be garnered but invested.

Investment means the turnover of money. It is self-evident that the rich and poor are both in demand of it. "Alms are for the poor and the needy, and those employed to administer the funds; for those whose hearts have been (recently) reconciled (to Truth); for those in bondage and in debt; in the cause of Allah; and for the wayfarer: (thus it is) ordained by Allah, and Allah is full of knowledge and wisdom" (The Holy Quran). 
Therefore, there is a need for a central link between the rich and the poor. The need of the poor for money can be met through physical or mental work or effort. This, however, is the same as the need of the rich for money through paying for physical and mental effort. Furthermore, this can only be achieved through investment.

So, the rich has two options: Hold over money. In this case, he will pay the money of zakat that will go to the poor (Money here decreases by inflation, zakat value, and family or individual consumption growth.) or investing it. In this case, investment will create job opportunities for the poor. Therefore, we find one of the zakat deservers: The one who work to administer it and the one who is in debt (bankrupt). Here, this is a kind of zakat. Therefore, in all cases, the money of zakat payer goes to consumption as a "motif". But how can we determine the minimum period and major period? Based on yearly duties and seasonal duties, the year is 12 months. Each month of the year has its duties which are different from month to month. For example, in the month of Ramadan, it is obligatory to perform breakfast zakat in addition to fasting. Also, it has a special expense in the month next to Ramadan known as the feast Special expense. In addition, the month of Hajj is also regarded as a Special expense. Therefore, we conclude from here that the minimum period considered is a month, while the major is a year. So, what is the meaning of the money rotation in a certain period, and why?

Rotation through a certain period is based on the value of money. This is because spending money means spending the first income as income is realized monthly (the minimum period) during the year (the major). Paying zakat at the end of the year would make someone spend less than the value of his/her monthly income. So any person whose spending exceeds the value of his monthly income deserves to pay zakat. Also, spending one-month income or more per year shows a difference between the rich and the poor.

In the case of extreme poverty, twelve (12) monthly income per month and so on, (11) M. I. P.M., (10) M.I.P.M., ......... The poverty line (1) M.I.P.M. In addition, a high income means a high zakat. Thus, less spending does not give a high zakat. Therefore, zakat is relatively positive to income. So, If (monthly consumption $\times 12$ ) < monthly income, then; Individual zakat $=2.5 \% \times(($ monthly income - monthly consumption $) \times 12)$. Else, Individual zakat $=0$.

In addition, when the income is less to buy a house at the turn of the year, the person who does not have a home may deserve zakat. This is despite the fact that his income achieves food satisfaction at least. This is because saving for the value of a home means that those who are saving are in need.

For example, if the annual saved income is 100 thousand, it means that he needs 10 years to buy a house worth 1 million. However, when the value of zakat is subtracted, this means that the value of zakat exceeded his savings for 
a full year (137500) plus the amount of inflation. Therefore, the wisdom of zakat is clear by investment and not by saving. In addition, investment means growth because there is a real growth in the population which must be matched by growth in money. So, the need for money is directly proportional to the population.

Also, there is what is called breakfast zakat in Islam. It has these qualities:

- Providing food, not money, despite the availability of money. This is because;

$\circ$ It engages maximum number of society members in providing this kind of zakat, which to this day does not exceed $\$ 10$ for everyone once every year.

- Food represents the main necessity for survival.

- It prevents everyone from saving a large quantity of money but rather moves the economy forward. Whereas, society at every level, poor and rich, usually has a high level of food consumption, especially for a society where most of them are farming. This kind of work is laborious and requires hard work. Despite that, they usually do not earn much.

- Inventory turnover, especially for food as a consuming product, are subjected to an expiry date.

- Food Security and Demand Stability as shown in Table 3 (approximate). Here, if we consider a variable quantity or variable meal, then:

$N T=(1 \div y) \times N B$, where, $y=((q \times 366) \div m$. $)$, and $(q)$ is quantity, $(m)$ is meal, (366) is year days, $(N B)$ is the number of people who are able to offer breakfast zakat, $(N T)$ is the number of people who take breakfast zakat and are subjected to; $y \leq(N B) \leq$ population number. $N B$ and $N T$ are integer. And if we suppose a fixed quantity and fixed meal, then a breakfast zakat fixed rate in a full year security food for number of people $(N T)$, by society members who are able to offer $(N B)$ is; $1 \div 61$. Then, $(N T)=(1 \div 61) \times N B$ is subjected to; $61 \leq(N B) \leq$ population number.

\begin{tabular}{|c|c|c|c|c|c|}
\hline Population & Quantity(K) & Meal* & Day & Food Security For & Demand Stability By \\
\hline 1 & 3 & 18 & 6 & & \\
\hline 61 & 183 & 1098 & 366 & $1.6393 \%$ & \\
\hline \multicolumn{5}{|c|}{ Day } \\
\hline \multicolumn{2}{|c|}{ Source: The Author } \\
\hline
\end{tabular}

Table 3. Approximated breakfast zakat of 61 person representing a Person full year food necessity. In same way, we can find figures of greater bairam bounty. 
This leads us to talk about begging. Prophet Muhammad dislikes and detests the begging for money according to Sahih Bukhari. However, Prophet Muhammad was with some of his companions who came as a guest but they were asking for food (Sahih Bukhari). So, what is unacceptable begging?

Unacceptable begging in the society is done as a trade or due to laziness such as begging for money. Here, it is worthy to state categorically that begging increases as envy increase. Envy is the wishing of acquisitions loss from others. So, begging for money and envy has the following common qualities;

○ Looking for what others have, instead of looking at what they have.

- An impassivity tendency trying to take others acquisition and it has a range: from the worst one envy, through thievery, and it ends with begging. However, when a request is made for food because of hunger, it is not called begging but hospitality. This is because by tradition and across cultures as a humanitarian aspect, any person regardless of his condition can come down to anyone to ask for food. This is because food is a necessity. Also, asking for clothing just like food and across culture was not considered as a kind of begging but it is presented as a kind of gift. However, this is because cloth in itself is a necessity.

In addition to zakat, there is a jurisprudential rule in Islam which says "do not cause harm or return harm." This often takes place between: An individual with another individual, a group and another group, or an individual and a group. However, the most important of them is that it should be between the rich and the poor, or an individual with a group because of an inequality of influence.

One of these cases involves the damage caused by the so-called issuance of instruments that are subject to capability or mandatory transfer to shares. This is because the owner of the share will lose a percentage of his ownership in the capital of the company or the project upon the conversion of those instruments into shares. This happened by an increase in the capital while keeping the number of shares owned by the shareholder unchanged. This entails a deduction from the return on the stock, equity, and the future growth opportunities of earnings per share. This is contrary to the principles of public partnership and the value of the money paid to buy or subscribe to the share. For example, if a stockholder has $10 \%$ of the company shares, the company issues instruments and convert it to shares by $100 \%$. Then, that ten percent becomes $5 \%$.

As a result, this is regarded as a clear damage and is unfair to the shareholder. So, this is clearly forbidden in Islam.

In addition, Islam strongly forbids certain capital practices such as usury, "That they took usury, though they were forbidden" (The Holy Quran). 
Usury refers to what raises over people's money or doubles over people's money. Also, usury in Arabic language is a word derived from what is "big and long and overpowering and evident." It has an Arabic language meaning whose tone sounds as "RUB" which means God. "TARBIAH" means something enlarged rapidly and, at the same time, it has to put up for a long time with feeding and maintenance. Also, "RABIAH" means hill.

Furthermore, usury was used in these qualities:

- It can only be lend out with high interest rate.

- Doubles over people's money

- Without doing a considerable job and without any considerable employment of resources.

Furthermore, it does not apply exactly to the banking systems because:

- Banks can both lend and borrow.

- Banks can offer a low interest rate. In addition, it can replace the direct debt method through participation.

- Banking activity is an employment of resources.

Here, we can apply the "little and much" legislation logic and also provides a proof and experiment as;

little $\leq$ the little and much $<((2.5 \%)+\mu+$ cost $)$.

Where $2.5 \%$ is the zakat rate as:

1. A criterion of the financial ability.

2. A value over unconsumed income.

ii. $\quad \mu=$ inflation $\div$ period.

iii. $\quad$ Cost $=$ fee $\div$ Amount.

iv. Little $=2.5 \%-((2.5 \%) \times($ consumed value $\div$ total value $))$.

$v$. Little here has direct proportion with consumption to reflect the financial ability.

\begin{tabular}{|c|c|c|c|c|c|}
\hline \multirow{2}{*}{ Inflation } & Period Per Year & \multirow{2}{*}{ Interest } & $\begin{array}{c}\text { Consumption } \\
\text { Rate }\end{array}$ & Little \\
\cline { 2 - 3 } & $3 \mathrm{Y}$ & $5 \mathrm{Y}$ & & $10 \%$ & $2.25 \%$ \\
\hline 0.010 & 0.003 & 0.002 & 0.027 & $20 \%$ & $2.00 \%$ \\
\hline 0.020 & 0.007 & 0.004 & 0.029 & $40 \%$ & $1.50 \%$ \\
\hline 0.040 & 0.013 & 0.008 & 0.033 & $60 \%$ & $1.00 \%$ \\
\hline 0.060 & 0.020 & 0.012 & 0.037 & $80 \%$ & $0.50 \%$ \\
\hline 0.100 & 0.033 & 0.020 & 0.045 & $0.00 \%$ \\
\hline 0.200 & 0.067 & 0.040 & 0.065 & $100 \%$ & $0.00 \%$ \\
\hline \multicolumn{7}{|c}{ Source: The Author } \\
\hline
\end{tabular}

Table 4. Example of the little and much logic. Here, interest is inversely proportional to period. At same time, little is inversely proportional to consumption rate.

At the same time, usury applies to some commercial phenomena that represent a bad behavior of capitalism such as land speculative because: 
- It can only afford high price as a high quantity of money needed to buy with would be an inequivalent value. Hence, it entails buying money with money.

- It doubles over people's money .

- Without doing a considerable job and, without any considerable employment of resources (Abdulaziz Jughaiman, 2017). Here, exist the main difference between the buying and selling process from the usury.

As the Holy Quran says "Those who consume usury shall not rise up (from their tomb) except as he who rises in madness that Satan has touched. That is because they say: 'Selling is like usury.' Allah has permitted trading and forbidden usury." Here, their allegation was that the interest from selling looks like the interest from usury. Also, many commercial phenomena are using the usury in the name of buying and selling as a kind of publicity. Ethically, the usury is only an ideology of the domination tenet, an unadulterated selfishness, and selfhood bearing. Since selling is offer, offer is supply. Furthermore, supply must meet ability equations as:

Ability + necessity (most people) Or Ability + welfare

Subsequently, usury can only meet ability. However, for capitalism to continue and become acceptable by the societies, it must get rid of its imperfections. On the other hand, Islam and moral logic does not reject the fact that a group of people can enjoy great wealth. This is the case if the sources of their wealth were legitimate, constructive, and not collected by exploiting politics or by corruption.

\section{Conclusion}

- I concluded in this present paper that the importance of adopting legislation on knowledge helps us to understand the laws and to respect human rights and their needs. Also, identifying the common factors of the community would help to enact more acceptable laws and offers a wider range of freedoms without creating a contradiction. In addition, I clarify the meaning of legal and individual opinions. This paper also highlighted the concept of destiny, mistake, and crime. And, the importance of a correct understanding of what is prohibition and what is permissible which helps us to understand what individual rights, freedoms mean, and what corruption means. I explain the fundamentals of legislation in Islam, and how to understand Islamic legislation in a way that respects human rights by explaining the meaning of punishment and sedition. In addition, I concluded the practical meaning of racism which enables us to resist the real racism.

- In the issues of polygamy in Islam as a woman right issue the paper shows that the percentage of polygamy female is only $0.1 \%$ of the total married female. In same time unmarried female within the age group 
of 15 to 49 years (with capability of pregnancy) represents a $76.9 \%$ to the total unmarried men. Beside this an approximately $2.11 \%$ of Saudi Labor female force can supports their family. Which creates a kind of discrimination in the issue of inheritance and polygamy regarding to family support. These issues are interrelated with each other to justify each other. this explains the Conservative society tendency towards family role that gives a priority over other roles and the society opinion towards woman. In addition, I clarified the polygamy issue as a woman and man decision rather than a man decision. Also, in the issue of marriage the paper shows the overlap between womb as Islamic fundamental with some local custom. In these issues I found these equations to calculate the polygamy rate and the rate of unmarried female to unmarried male:

polygamy rate $=\left[\sum_{k=15}^{n=65}+\right.$ married female -

○ $\sum_{k=15}^{n=65}$ married male $] \div \sum_{k=15}^{n=65+}$ married female.

unmarried female with pregnancy capability to unmarried male $=$ $\left[\sum_{k=15}^{n=49}(\right.$ widowed females + divorced females +

never married) $] \div \sum_{k=15}^{n=65+}$ (widowed male + divorced male +

- never married male $+(($ polygamy rate $) \times$ married male $))$

In addition, I clarify the legislation of women's dress regarding to society nature and woman rights.

- In the issues of money in Islam and its role as a humanitarian necessity in economic development and the rights of poor people. I concluded the difference between the rich and the poor by this equation: If (monthly consumption $\times 12)<$ monthly income, Then; Individual zakat $=2.5 \% \times(($ monthly income - monthly consumption $) \times 12)$. Else, Individual zakat $=0$. Also, I concluded that money zakat is aimed at money turnover, while breakfast zakat aims at Inventory turnover. In addition, I concluded the qualities of breakfast zakat as food security, and demand stability. If we consider a variable quantity or variable meal, then,

○ $N T=(1 \div y) \times N B$, where, $y=((q \times 366) \div m$. $)$, and $(q)$ is quantity, $(m)$ is meal, $(366)$ is year days, $(N B)$ is the number of people who able to offer breakfast zakat, $(N T)$ is number of people who take breakfast zakat. They are subjected to; $y \leq(N B) \leq$ population number. $N B$ and $N T$ are integer.

O $1 \div y$ is the rate

Also, I clarify Some unacceptable behaviors such as begging regarding to human rights. In addition, from the Islam jurisprudential rule that says; whatever intoxicates in large quantities, a small quantity of its forbidden, I explained that the forbidden here is related to the element 
of quantity and element of necessity and concluded the "little and much" legislation logic as: Permissible $\leq$ little and much $<$ Prohibition. I abbreviated by; "LP. $\leq L . A . M .<M P$." and I applied it to the bank system regarding to the issue of usury. Where $2.5 \%$ is the zakat rate as a criterion of the financial ability and a value over the unconsumed income. Also, I explained the forbidden usury qualities and its concepts compared to the concept of banking systems and its qualities. In addition, I explained an application of the Islam jurisprudential rule that says, "do not cause harm or return harm ", regarding to people rights.

\section{References:}

1. Abdulaziz Jughaiman (2017). Land as a Factor of Production and Scarce Resource. European Scientific Journal, 197,175-201.

2. Eric Rasmusen (1989). Games and information. ( $\left.2^{\text {nd }} E D.\right)$. Blackwell publishers.: unit (1).

3. Eric Wolf \& Fadhel Jutkur (2004). Europe and the people Without History. ( $1^{\text {st } E D .) . ~ A r a b ~ O r g a n i z a t i o n ~ f o r ~ T r a n s l a t i o n: ~ U n i t ~(7), ~ P a g e ~}$ $(299,300)$.

4. General Authority for Statistics Kingdom of Saudi Arabia, Demographic Research Bulletin 2017. https://www.stats.gov.sa/en

5. General Authority for Statistics Kingdom of Saudi Arabia, Labour Force Survey, Q3 2016. https://www.stats.gov.sa/en

6. Peter Kunzmann, Franz-Peter Burkard, Franz Wiedmann, Axel Weib, George Katorah (1991). DTV-Atlas Philosophie. ( $8^{\mathrm{TH}}$ ED.). East Library: Units (6).

7. Richard Branson, Hassan Hosni Al-Ghabari, \& Mohammed Ibrahim Younis (1988). Operations Research. (1 ${ }^{\mathrm{st} E D}$.). International publishing house. Unit (21). 